Urban Design and Planning

Volume 170 Issue DP6

Embedding sustainability criteria into pre-appraisal of underground utility for future cities

Hojjati, Jefferson, Metje and Rogers
Proceedings of the Institution of Civil Engineers

Urban Design and Planning 170 December 2017 Issue DP6

Pages 258-271 http://dx.doi.org/10.1680/jurdp.17.00023 Paper 1700023

Received 22/08/2017 Accepted 02/10/2017

Published online 29/11/2017

Keywords: infrastructure planning/sustainability/

town \& city planning

Published with permission by the ICE under the CC-BY 4.0

license. (http://creativecommons.org/licenses/by/4.0/) ice

Institution of Civil Engineers

\title{
Embedding sustainability criteria into pre-appraisal of underground utility for future cities
}

1 Aryan Hojjati MEng, AFHEA

PhD Candidate, Department of Civil Engineering, School of Engineering, University of Birmingham, Birmingham, UK (corresponding author: a.hojjati@pgr.bham.ac.uk) (Orcid:0000-0002-2928-5025)

2 Ian Jefferson BEng, DIS, PhD, FGS

Professor of Geotechnical Engineering, Head of Education, School of Engineering, University of Birmingham, Birmingham, UK (Orcid:0000-0001-6437-101X)
3 Nicole Metje Dipl.- Eng, PhD, MCInstCES, MASCE, FHEA Reader in Infrastructure Monitoring. Head of the Power and Infrastructure Research Group, School of Engineering, University of Birmingham, Birmingham, UK (Orcid:0000-0002-6741-8183)

4 Christopher D. F. Rogers Eur Ing, BSC, PhD, CEng, MICE, MIHT

Professor of Geotechnical Engineering, Director of the UKCRIC National Buried Infrastructure Facility, School of Engineering, University of Birmingham, Birmingham, UK (Orcid:0000-0002-1693-1999)
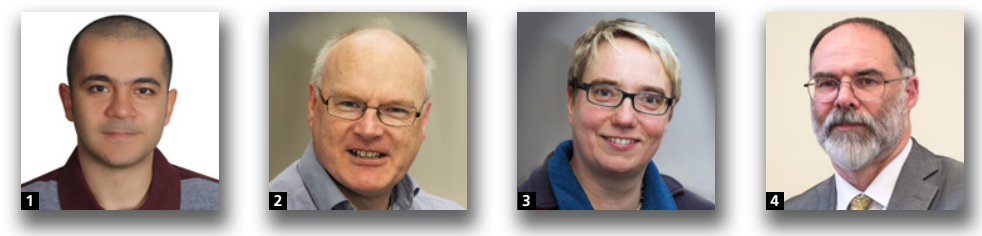

The underground utility infrastructure (UUI) will play a crucial role in meeting the demand for creating sustainable and resilient urban developments that are fit for purpose today and in the far future. The utility streetworks operations, an important feature of the UUI system, include placement, maintenance, rehabilitation, renewal and upgrading of UUI, which can have adverse economic, social and environmental impacts. A key challenge, and one that will lead to lost opportunities for the best use of the near surface for utility provision for future cities, is the lack of a sustainability indicator system and assessment method for evaluating different utility streetworks solutions. To address this shortfall, this paper presents a new suite of indicators, or performance criteria, bespoke to utility streetworks projects as well as a pre-appraisal method based on the adaptation of the Arup SPeAR $^{\circledR}$ sustainability evaluation framework. An example of the application of the modified system is provided for a trenchless against trenching case study, and the lessons that flow from this are discussed in the wider context of the synthesis of utility service operations into sustainable, resilient, smart and liveable cities of the future.

\section{Introduction}

The underground utility infrastructure (UUI) system is a vital element in the successful performance of an urban system of systems. Its efficacy will increasingly become a major criterion for the success of the future of cities, as the demand for utility provision continues to rise due to continuing increases in both populations and the proportion of people living in cities. Thus, UUI within the urban underground space agenda (Hunt et al., 2016), and its associated urban streetworks, will have an important role in improving the sustainability, liveability and resilience of modern urban environments.

It is reported that in 2014-2015, an estimated 1.4 million streetworks were undertaken by utility companies in the United Kingdom alone, which equates to more than $2 \cdot 4$ million road openings (Gallienne, 2016). Exacerbation of increasing traffic congestion on urban roads worldwide is one of the many wider impacts of streetworks and this is intensified by inaccurate detection and location of underground assets (McMahon et al., 2006). This is not a new problem, but it is being worsened by the increasing number of utility streetworks operations around the world (Metje et al., 2007). An important risk inherent in more prevalent streetworks, therefore more numerous excavations, is incremental damage to existing underground utilities (e.g. loss of ground support) and the occurrence of utility strikes, with enormous economic as well as indirect costs and impacts to the society (Makana et al., 2016; Metje et al., 2015). This forms only part of the wider costs and impacts of UUI streetworks operations, which include air and noise pollution, increased accident rates and the creation of waste (materials, energy), and therefore needs long-term impact assessment - or sustainability evaluation - within a valuebased asset management framework (Hojjati et al., 2016, 2017). This challenge is being addressed through the 'Assessing 
Embedding sustainability criteria into pre-appraisal of underground utility for future cities

Hojjati, Jefferson, Metje and Rogers

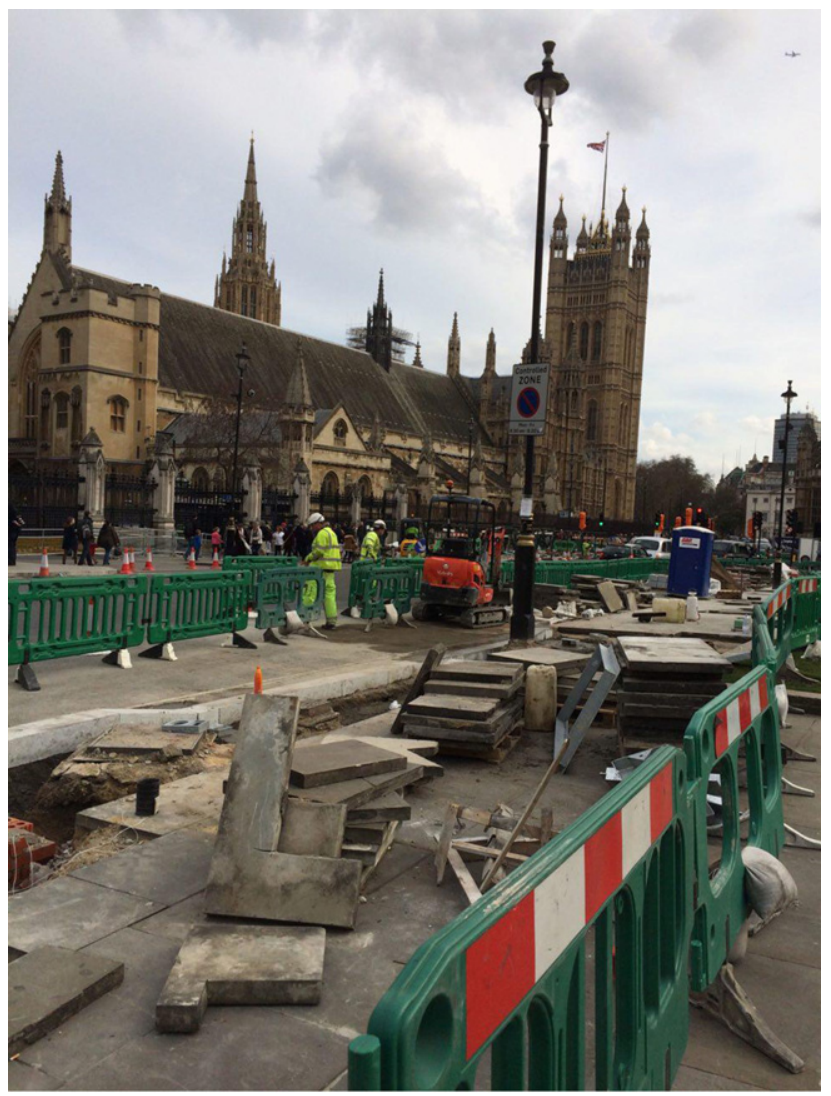

Figure 1. Conventional utility streetworks and associated disruptions in the City of London

The Underworld' (ATU) project (Rogers, 2015; Rogers et al., 2012a).

Several different alternative practices for utility installation exist, including multi-utility tunnels (MUTs) and various trenchless technologies, such as pipe jacking, impact moling and horizontal directional drilling (HDD). However, decisions are mainly made on a direct cost basis, focused on short-term construction costs, with little consideration of longer-term economic, social and environmental consequences for the choices made (Figure 1). Failure to engage with long-term impacts and consequences of streetworks will 'lock in' operational functions and behaviours that are significantly less sustainable and resilient into the future of cities utility infrastructure landscape for many years to come. This will also limit choices for doing things differently and therefore perpetuate failed opportunities to provide future proofing (Masood et al., 2016) - for example through novel and sustainable use of the near sub-surface underground urban space.

To address this important agenda and minimise the envisaged future impacts, and costs, to the cities, we live in, as a result of increasing utility streetworks, there is a need for decision-making systems that incorporate sustainability criteria and assessment methodologies. The research presented in this paper provides the basis for such evaluations by developing a pre-appraisal indicator system and assessment methodology.

\section{Background: sustainability indicator systems for utility infrastructure projects}

To develop a robust and comprehensive sustainability indicator system and framework for streetworks activities - an essential component of a decision support tool for the choice of the most sustainable option for utility works - a critical review of the available sustainability assessment tools and indicator systems was carried out (Hojjati et al., 2017). The results of this review led to the adaptation of the well-established software-based Sustainable Project Appraisal Routine (SPeAR ${ }^{\circledR}$ ) sustainability assessment tool. Developed by Arup in 2000 and upgraded in 2011, the tool is a decision-making framework used to improve the economic, social and environmental performance of projects and processes (Arup, 2017). It produces colourcoded diagrams as outputs of the sustainability assessment based on a traffic-light scoring scale (Figure 2). It has been applied to many different types of projects, including master planning (McGregor and Roberts, 2003), acoustics (Braithwaite and Cowell, 2007), company performance (Braithwaite, 2007), environmental geotechnics (Jefferson et al., 2007), foundation reuse (Laefer, 2011), and geotechnical engineering projects (Holt et al., 2010).

Proposals have been made for sustainability criteria and assessment frameworks for urban infrastructure systems (e.g. Sahely et al., 2005), while others have provided evaluation criteria and indicators for alternative utility engineering practices (Ariaratnam et al., 2013; Jung and Sinha, 2007; Koo et al., 2009; Najafi and Kim, 2004), but none offers a comprehensive list of criteria across the three pillars of sustainability for utility streetworks projects in urban environments. To address this omission and to contribute to the body of knowledge in the field of sustainable infrastructure, the pre-appraisal version of the Arup SPeAR $^{\circledR}$ (Oasys, 2017) was adapted and the set of indicator systems modified to cover all aspects of utility streetworks for placement, rehabilitation, renewal and maintenance of UUI. An advantage of the tool is that it is not 'reward-driven', a feature that normally creates an 'in-built bias' in the framework. It is also a robust, flexible and easy-to-use system, which is developed based on sets of widely recognised sustainability indicators, such as the UN indicators for sustainable development and the UK government's sustainability indicators set (Braithwaite, 2007; Hojjati et al., 2017; Holt et al., 2010). These were among the main reasons to choose it to be adapted in this research. 


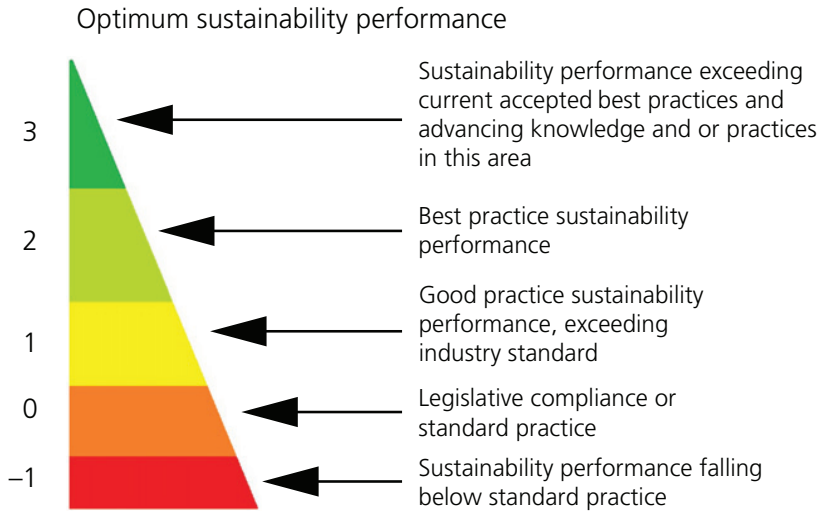

Worst case sustainability performance

(a)

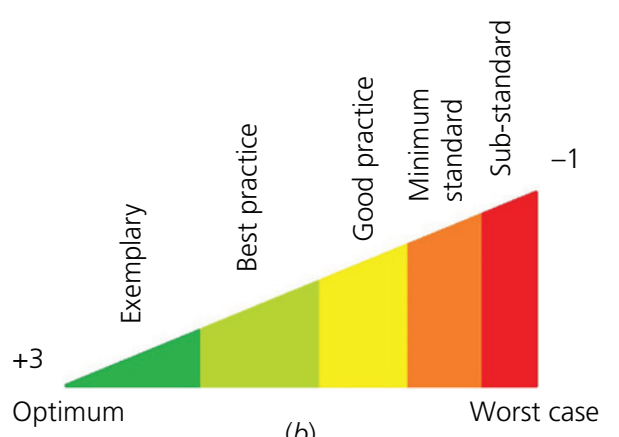

(b)

Figure 2. (a and b) Explanation of $S P e A R^{\circledR}$ rating and scoring system (Adapted from Oasys (2012)) - Reproduced under Oasys Software UNIPAC Engineering Suite for Research Licence. A fullcolour version of this figure can be found on the ICE Virtual Library (www.icevirtuallibrary.com)

The pre-appraisal version of the tool is a new, simplified version that aims to address, identify and assess sustainability issues at the early stages of a project's lifecycle (Figure 3). Similar to the full version, it provides a robust, flexible and auditable system to demonstrate a project's sustainability assessment performance in a visually accessible manner.

\section{The model: sustainability criteria and modifications for utility streetworks assessment}

The SPeAR ${ }^{\circledR}$ framework has been modified for different purposes over the years. For example, Laefer (2011) developed a six-point scoring scale to provide a more quantitative supplement to the system, while Holt et al. (2010) proposed the use of life-cycle analysis (LCA) alongside it. Zargarian et al. (2016) attempted to add weightings to the tool's indicators system for underground space sustainability assessment; however, this led to greater subjectivity and decreased its flexibility when judged across different projects.

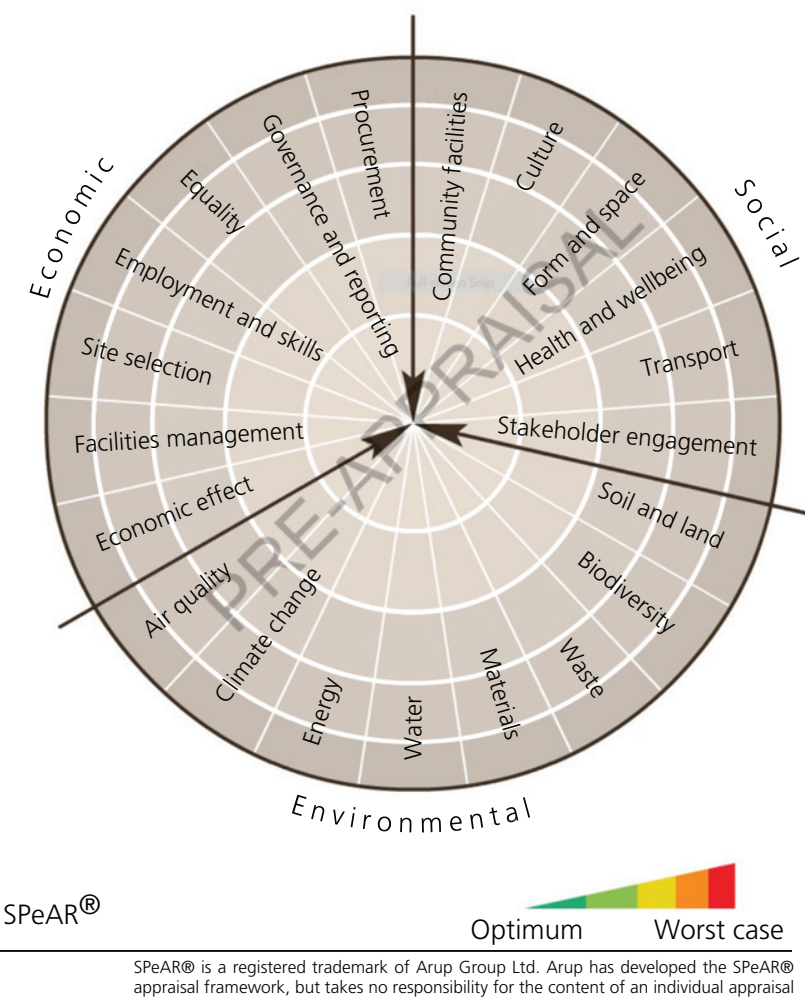

Figure 3. Template of the Arup SPeAR ${ }^{\circledR}$ Pre-Appraisal Software (Oasys, 2017) (reproduced under Oasys Software Unipac Engineering Suite for Research Licence). A full-colour version of this figure can be found on the ICE Virtual Library (www. icevirtuallibrary.com)

The pre-appraisal version was chosen to be modified for use as part of a novel value-based sustainability decision support framework to be applied at the early stages of a streetworks project when few decisions have been made. It will be followed by a detailed evaluation of costs and benefits (hence portfolio of values) of different project alternatives and postassessment comparison during the application of the full framework.

The three primary categories of economic, social and environmental impacts were retained, but with a particular focus on indirect economic impacts within the economic category. Thus for streetworks, the broad categorisation is direct impacts (e.g. temporary excavation costs) and indirect impacts (e.g. costs due to damage or loss of service life borne by owners of assets other than that being addressed specifically by streetworks, such as utility companies and/or those responsible for the transport infrastructure beneath which they are buried) under the economic category, social impacts (the combination of beneficial and adverse impacts borne by society as a whole) and environmental impacts. Thus, the total 
Table 1. Initial criteria for utility streetworks sustainability assessment (adapted from Hojjati et al., 2016)

\begin{tabular}{|c|c|}
\hline Headline indicator & Main criteria \\
\hline \multirow[t]{5}{*}{ Construction direct economic impact } & Planning and design \\
\hline & Labour and machinery (skills and equipment) \\
\hline & Construction materials \\
\hline & Temporary construction works \\
\hline & Traffic management \\
\hline \multirow[t]{5}{*}{ Maintenance direct economic impact } & Planned maintenance \\
\hline & Monitoring \\
\hline & Access to services \\
\hline & Emergency repairs \\
\hline & Decommissioning \\
\hline \multirow[t]{5}{*}{ Construction indirect economic impact } & Third-party utility damage \\
\hline & Compensation to businesses for loss of profit \\
\hline & Compensation to customers for interruptions to services \\
\hline & Loss of income to asset owners or utilities \\
\hline & Compensation to local authorities for damage to their assets \\
\hline \multirow[t]{5}{*}{ Maintenance indirect economic impact } & Loss or damage to companies' brand image \\
\hline & Required training (upskill) \\
\hline & Insurance \\
\hline & Loss of business to competitors \\
\hline & Lost opportunity cost \\
\hline \multirow[t]{5}{*}{ Construction social impact } & Delay costs to road users \\
\hline & Disruption to businesses \\
\hline & Disruption to local community \\
\hline & Health and safety (nuisance) \\
\hline & Costs to local authorities \\
\hline \multirow{5}{*}{ Maintenance social impact } & Delay costs to road users \\
\hline & Disruption to businesses \\
\hline & Disruption to local community \\
\hline & Health and safety (nuisance) \\
\hline & Costs to local authorities \\
\hline \multirow[t]{5}{*}{ Construction environmental impact } & Energy efficiency (production, transportation, consumption) \\
\hline & Materials and waste production \\
\hline & Carbon footprint (embodied and operational) \\
\hline & Water consumption and pollution \\
\hline & Biodiversity (flora and fauna) \\
\hline \multirow[t]{5}{*}{ Maintenance environmental impact } & Energy efficiency (production, transportation, consumption) \\
\hline & Materials and waste production \\
\hline & Carbon footprint (embodied and operational) \\
\hline & Water consumption and pollution \\
\hline & Biodiversity (flora and fauna) \\
\hline
\end{tabular}

sustainability impact of streetworks is defined as

Total Sustainability Impact $=$ Economic $[$ Direct + Indirect $]$ Impact + Social Impact + Environmental Impact

Each headline indicator was initially categorised into construction (short-term) and operation and maintenance (long-term) phases, to which the main criteria were allocated (40 main criteria across eight different categories, Table 1). The rationale for considering short- and long-term impacts, between some of which there is duplication, is to be explicit in the capture of the total beneficial and adverse impacts throughout the lifecycle of utility streetworks projects - transparency and comprehensiveness are two of the main barriers for implementation of long-term systems thinking.

An initial portfolio of criteria was drawn from the literature: McMahon et al. (2006), Rogers and Hunt (2006), Jefferson et al. (2007), Hunt et al. (2008), Holt et al. (2010), Jung (2012), Hayes et al. (2012), Pearce et al. (2012), Ariaratnam et al. (2013), Hunt et al. (2014) and Metje et al. (2015). The criteria were reviewed and revised following three expert panel discussions with experts from the utilities and sustainability business sectors, and were used as the basis of consultation with a wide range of industry experts and stakeholders (Figure 4) to refine and validate the indicators and assessment criteria using a structured questionnaire survey. The 
Embedding sustainability criteria into pre-appraisal of underground utility for future cities

Hojjati, Jefferson, Metje and Rogers

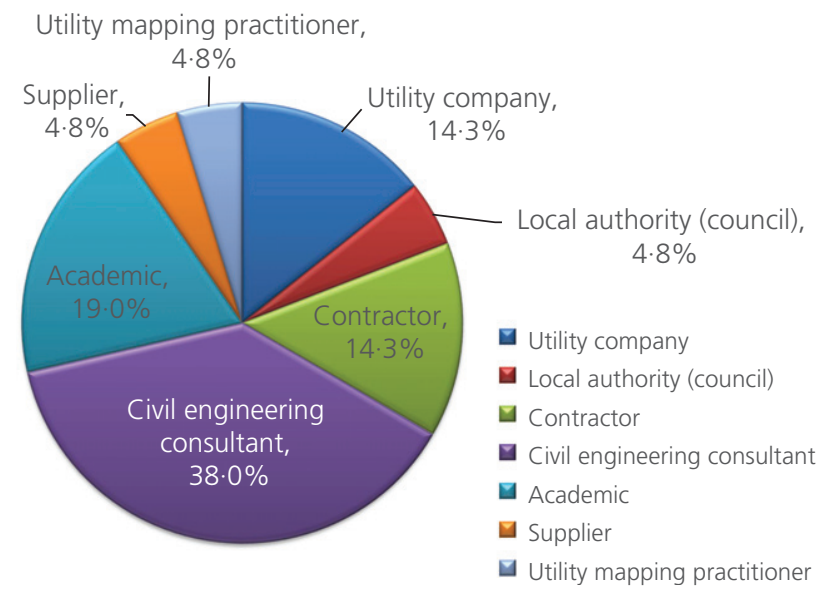

Figure 4. Distribution (\%) of participants for the utility streetworks sustainability criteria questionnaire survey. A fullcolour version of this figure can be found on the ICE Virtual Library (www.icevirtuallibrary.com)

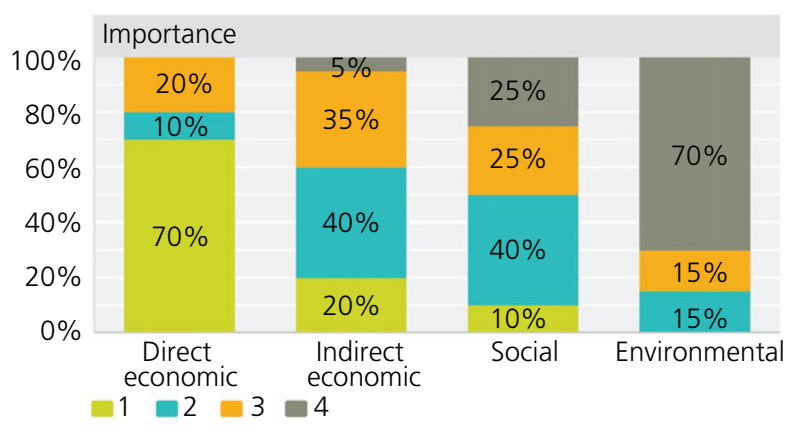

Figure 5. Question regarding the relative importance of headline indicators. A full-colour version of this figure can be found on the ICE Virtual Library (www.icevirtuallibrary.com)

questionnaire aimed specifically to capture expert opinion on the importance and applicability of the criteria.

In addition, more detailed interviews were conducted with selected participants from across the industry. These include urban underground infrastructure consultants, local authorities, civil engineering contractors, civil engineering consultants, subsurface utility surveyors and academics at technical universities. The interviews were conducted both in the United Kingdom and in the Netherlands. The results of the questionnaire and the more detailed interviews were used to inform the pre-appraisal tool and indicator system within the sustainability assessment framework for urban utility streetworks. Examples of the survey questions and a summary of the collective answers of the participants are demonstrated in Figures 5-7.
In the first round of expert panel meetings, discussions were based on indicators drawn from the literature. For example, 'labour and machinery' (as a direct economic construction criterion) was created after an expert panel discussion on a previously used criterion termed in the literature simply as 'payments', under which labour (as a sub-criterion) was placed. It is important that 'labour' is recognised as a main criterion: one that constitutes a major direct economic cost for streetworks projects and which has sub-categories of criteria under it - this helps to deliver the necessary transparency.

Moreover, greater clarification of the distinction between short- and long-term impacts has been introduced by reappraising the criteria within the operation and maintenance direct economic headline. An example of this is selecting 'monitoring' as a main category in which asset location techniques (including both destructive methods and nondestructive geophysical methods, such as seismic, groundpenetrating radar (GPR), electrical or gravitational field techniques) sits as a sub-criterion. Similar discussions took place to refine the initially developed categories and criteria. A summary and examples of the comments from experts on the indicators system and assessment criteria, drawn from the questionnaire survey, interviews and calibration workshops, are presented in Table 2 .

Figure 5 indicates the views of the participants in terms of the importance of each headline indicator (direct economic, indirect economic, social and environmental) on a scale of 1-4, where 1 is the most important and 4 is the least important. This in itself is revealing.

Figures 6 and 7 present the participants' responses to the questions on the importance of the proposed main criteria within the four headline categories for construction (short term) and operation and maintenance (long-term) stages, respectively, as listed in Table 1. The question format for all of the responses shown was: 'Based on your past experience, please rank the cost/impact indicators for [short-/long-term] costs and impacts of utility streetworks by putting them in order of importance for each of the categories below ( 1 is the most important and 5 is the least important)'.

Figure 6 shows that there is significant consensus around the most important criteria in each category. Planning and design, which includes sub-criteria of surveys, risk assessment, administration and capital cost assessment, is the dominant priority in the direct economic category (Figure 6(a)). Similarly, thirdparty utility damage (with sub-criteria such as damage to other existing utilities, utility strikes) is the dominant priority in the indirect economic category (Figure 6(b)), while health and safety (with sub-criteria including traffic or road accidents, injuries to motorists, pedestrians and site operatives, collapse 


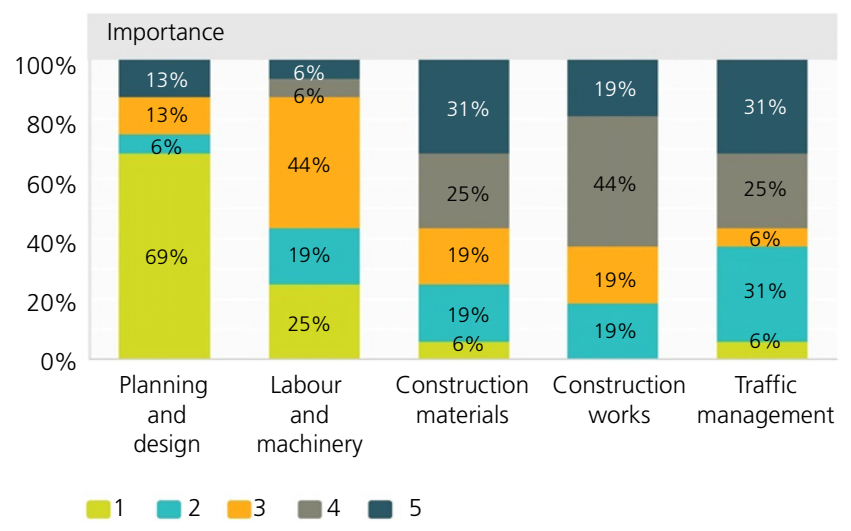

(a)

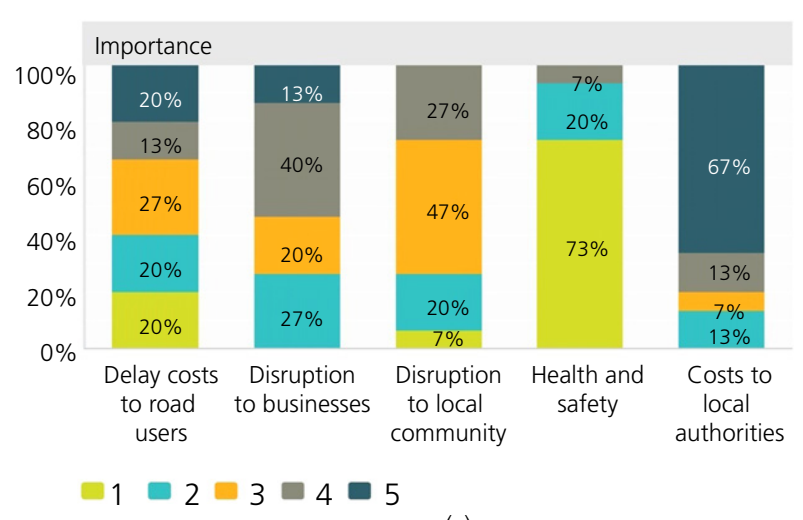

(c)

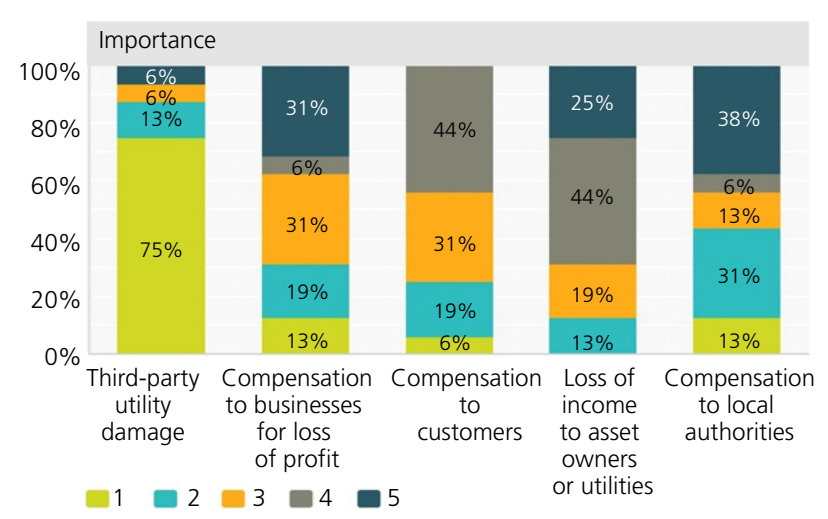

(b)

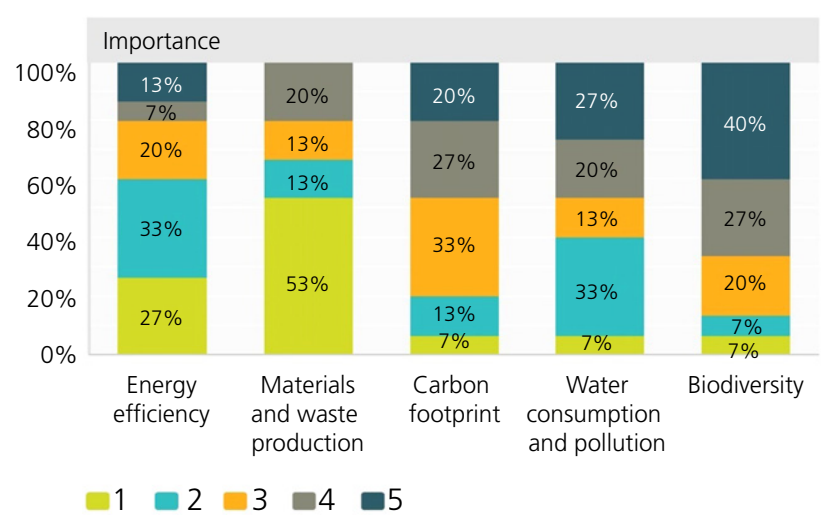

(d)

Figure 6. Survey responses on the importance of proposed short-term main criteria for construction: (a) direct economic, (b) indirect economic, (c) social, and (d) environmental. A full-colour version of this figure can be found on the ICE Virtual Library (www. icevirtuallibrary.com)

of trench sides and contact with underground services) dominates in the social category (Figure 6(c)). However, the distribution in the social category showed a particular feature that was absent in the other three categories: the lowest priority, with a strong consensus, was costs to local authorities, and yet these are costs that are borne by the society as a whole. Indeed, the distribution in this category is highly revealing and will evidently influence decision making: while health and safety is undoubtedly, and perhaps rightly, the urban professionals' first priority, there is little focus on how to bring greatest benefits to citizens, the ultimate beneficiaries of the utility services that are under consideration (Rogers, 2017). Priorities were more evenly distributed in the environmental category (Figure 6(d)), although interestingly materials and waste production (with sub-criteria of use of primary aggregates for backfill and the use of land for tipping waste) was considered more important than energy efficiency; perhaps understandably, biodiversity scored lowest and thus the focus of urban professionals is strongly on materials and resources when considering environmental matters. Recognising that it might not change this balance of priorities, it raises the question of how well the societal benefits of biodiversity, and urban nature more generally, are appreciated by these urban professionals.

Figures 7(a)-7(d)) demonstrate the survey participants' longterm priorities for the operation and maintenance stage of utility streetworks projects. In the direct economic category (Figure 7(a)), both planned maintenance and monitoring featured as strong first priorities - for both utility services and road surfaces - although there was an interesting bi-modal split in the latter: it either featured as a high priority or a low priority; a pattern that was even more starkly emphasised if decommissioning (which scored remarkably poorly) is removed from consideration. Goodwill, which includes damage to companies' brand image, ranked marginally higher than 
Embedding sustainability criteria into pre-appraisal of underground utility for future cities

Hojjati, Jefferson, Metje and Rogers

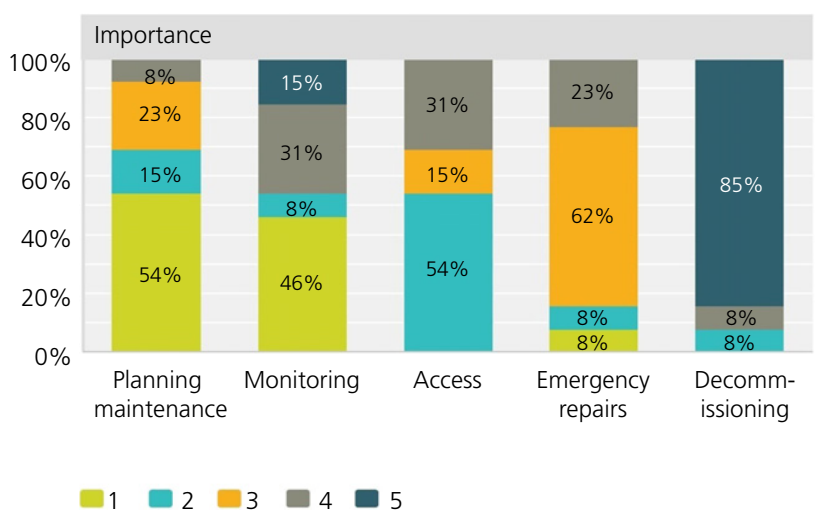

(a)

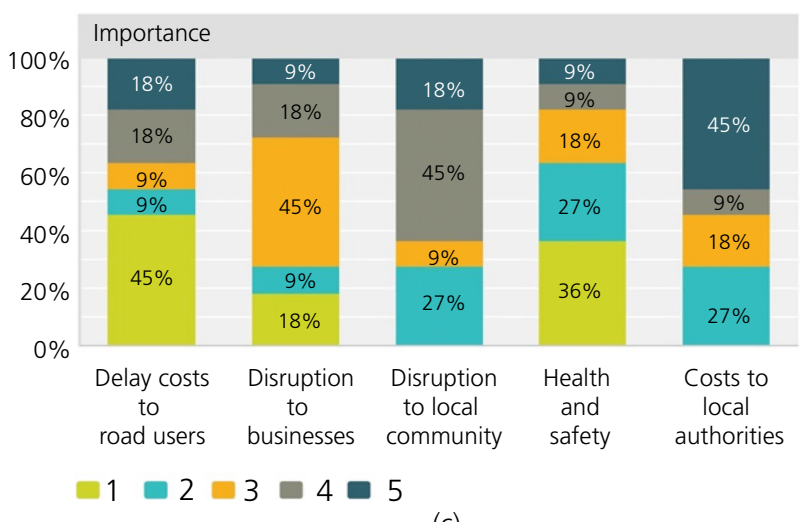

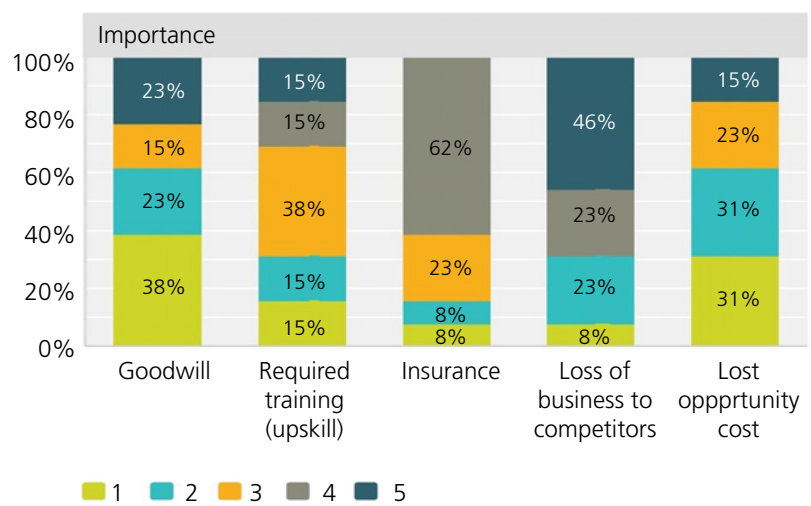

(b)

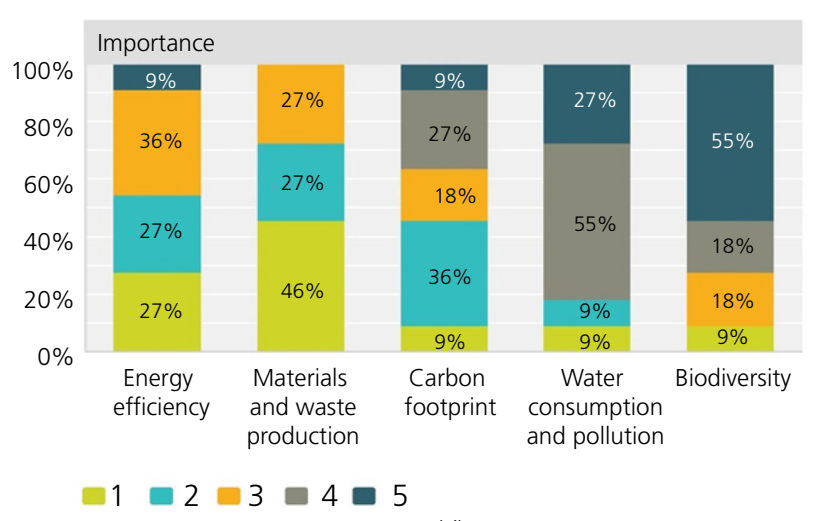

(d)

Figure 7. Survey responses on the importance of proposed long-term main criteria for operation and maintenance: (a) direct economic, (b) indirect economic, (c) social, and (d) environmental. A full-colour version of this figure can be found on the ICE Virtual Library (www. icevirtuallibrary.com)

lost opportunity cost in the indirect economic category (Figure 7(b)), although the priorities were more evenly spread in this category. Interestingly delay costs to road users (through the need to use diversion routes, and queuing and moving slowly through works, thereby increasing the journey time) was ranked higher than health and safety (which included health-related and compromised wellbeing due to problems caused by air and noise pollution, increases in human stress levels, etc.) in the social category (Figure 7(c)); health and safety is therefore far more of a short- than a long-term issue. Long-term concerns over materials and waste production and resources generally (Figure 7(d)) in the environmental category were not dissimilar to the short-term concerns (Figure 6(d)), although long-term energy efficiency concerns were marginally greater, while materials and waste production concerns were marginally reduced and future water consumption and pollution was markedly less of a priority; biodiversity also reduced in importance. These two figures bear scrutiny in terms of their likely influences on decision making.
Considering all comments from expert panel consultations, the questionnaire survey and interviews, a final set of headline indicators and main criteria bespoke to urban sub-surface utility streetworks projects were developed (Table 3). These criteria were embedded within the tool for sustainability assessment of alternative engineering practices for streetworks projects. One of the advantages of the Pre-Appraisal SPeAR ${ }^{\circledR}$ framework is that it is flexible and auditable, that is the original criteria and sub-criteria within the system under the three main categories (economic, social and environmental) can be changed or removed and new ones can be added. This can be done without compromising the original design thinking of the scoring system of the tool. This feature has been used to modify the tool to match the requirements of the utility streetworks projects and to create a bespoke pre-appraisal system for this purpose. Direct and indirect economic impact categories were amalgamated under the economic headline indicator for both construction and operation and maintenance stages to match the initial design thinking of the tool. Based on the 
Table 2. Examples of expert comments on the indicator system and assessment tool

\begin{tabular}{|c|c|}
\hline Summary of comments & Applicable to the indicator/criteria/tool \\
\hline $\begin{array}{l}\operatorname{SPeAR}^{\circledR} \text { diagram sections (main criteria) should be equally weighted and balanced. } \\
\text { Using weightings for indicators creates an in-built bias for the tool. }\end{array}$ & Modified Pre-Appraisal SPeAR ${ }^{\circledR}$ tool. \\
\hline Consider lane rental as a sub-criterion under traffic management. & Traffic management in direct economic category. \\
\hline $\begin{array}{l}\text { Compensation to customers comes through outage charges for disruptions to } \\
\text { service; it is not paid directly to the customer. }\end{array}$ & $\begin{array}{l}\text { Compensation to customers for interruptions to } \\
\text { services in indirect economic category. }\end{array}$ \\
\hline $\begin{array}{l}\text { [To construct a MUT] the build would be more difficult in the urban areas due to } \\
\text { the already congested roads and footways that would mean any utility tunnel } \\
\text { would need to go deeper, which in essence is fine but then you still need to bring } \\
\text { services from this tunnel to the end users, be it gas, water, electric or } \\
\text { communications, which in turn would require extensive excavations due to depth } \\
\text { and the traffic management to support this would be considerable. }\end{array}$ & $\begin{array}{l}\text { Construction works and traffic management in direct } \\
\text { economic category. }\end{array}$ \\
\hline $\begin{array}{l}\text { For labour and machinery, the terminology can be changed to skills and equipment } \\
\text { and this criterion should include sub-criteria of new technologies for new } \\
\text { machines and tools. }\end{array}$ & Labour and machinery in direct economic category. \\
\hline $\begin{array}{l}\text { For both carbon and energy, embodied and operational types for production, } \\
\text { transportation and consumption should be taken into account. }\end{array}$ & $\begin{array}{l}\text { Energy efficiency and carbon footprint in } \\
\text { environmental category. }\end{array}$ \\
\hline $\begin{array}{l}\text { Before determining design/construction methods, performing subsurface utility } \\
\text { engineering per PAS } 128 \text { (BSI, 2014) allows engineers/constructors to assess the } \\
\text { existing conditions to better determine design/construction application. }\end{array}$ & $\begin{array}{l}\text { Third-party utility damage in indirect economic } \\
\text { category. }\end{array}$ \\
\hline $\begin{array}{l}\text { Not sure I like the fact that there is a category for third-party utility damage; it gives } \\
\text { the impression that there will always be such an occurrence. }\end{array}$ & $\begin{array}{l}\text { Third-party utility damage in indirect economic } \\
\text { category. }\end{array}$ \\
\hline $\begin{array}{l}\text { It is suggested to use emissions instead of carbon for both construction and, } \\
\text { operation and maintenance stages of the projects' lifecycle as it is not only } \\
\text { carbon-associated emissions (e.g. carbon monoxide and carbon dioxide), but also } \\
\text { other pollutants such as nitrogen oxides, hydrocarbons, sulfur oxides and } \\
\text { particulate matters. }\end{array}$ & $\begin{array}{l}\text { Construction and maintenance emissions in } \\
\text { environmental category. }\end{array}$ \\
\hline $\begin{array}{l}\text { It is more impact on local authorities' assets rather than cost to local authorities, as } \\
\text { any disruption to other utilities or city services as a result of streetworks would } \\
\text { have an impact on local authorities' assets in urban areas. }\end{array}$ & Impact on local authorities' assets in social category. \\
\hline Wastewater management and drainage should be added to the water criteria. & Water in environmental category. \\
\hline
\end{tabular}

feedback from sustainability experts, the distribution of main criteria yielded an equal number of criteria with the same weight in all indicator categories - an outcome that perhaps helps to maintain balance and to avoid subjective bias within the assessment system, but not an essential requirement. The pre-appraisal tool translates the project information into economic, social and environmental impacts, which are then assessed using the system's scoring scale for both construction (short term) and operation and maintenance (long-term) stages of the project for each available alternative construction approach. Comparison of the results provides a transparent assessment of the sustainability performance of each option.

The methodology builds on the learning from previous research into future urban sustainability (Lombardi et al., 2011), resilience (Rogers et al., 2012b) and liveability (Leach et al., 2017), and is intended for use alongside the 'designing resilient cities' methodology, which establishes the likely performance of urban interventions in four 'extreme-yet-plausible' future scenarios, thereby enabling their modification to ensure that actions taken today are likely to deliver their intended benefits into the long term (Lombardi et al., 2012) - it makes the interventions more resilient to future change. Equally it should be used in parallel with the 'liveable cities' methodology (Hunt and Rogers, 2015; Leach et al., 2017) and aspirational futures methodology (Rogers, 2017), which seek to align the intended benefits with city and citizen aspirations and societal wellbeing, and the creation of alternative business models that take into account a broad interpretation of value when considering infrastructure interdependencies (Dawson et al., 2014).

The main purpose of synthesising this diverse, cutting-edge research thinking for utility streetworks is to move towards far more sustainable and resilient infrastructure by establishing a method for assessing 'value' as well as 'cost' across the full range of environmental, social and economic dimensions. It not only moves judgements away from a 'single bottom line' approach to decision making, but also shifts the focus of service delivery from the current context to embrace also (potentially very different) future contexts. The outcomes of this work naturally sit alongside the technical considerations of infrastructure asset degradation due to physical, chemical and environmental (including biological) processes, which influence the ability of infrastructure assets to deliver their desired functions over their intended lifespans. This thinking is embedded 
Table 3. Final set of indicators and criteria for sustainability evaluation of urban utility streetworks

\begin{tabular}{|c|c|}
\hline Headline indicator & Main criteria \\
\hline $\begin{array}{l}\text { Construction (short-term) } \\
\text { economic impact }\end{array}$ & $\begin{array}{l}\text { Planning and design } \\
\text { Skills and equipment } \\
\text { Construction materials } \\
\text { Traffic management } \\
\text { Third-party utility damage } \\
\text { Service disruption cost }\end{array}$ \\
\hline $\begin{array}{l}\text { Operation and maintenance } \\
\text { (long-term) economic impact }\end{array}$ & $\begin{array}{l}\text { Planned maintenance } \\
\text { Access and monitoring } \\
\text { Emergency repairs } \\
\text { Required training } \\
\text { Permitting charges } \\
\text { Long-term business loss }\end{array}$ \\
\hline $\begin{array}{l}\text { Construction (short-term) } \\
\text { social impact }\end{array}$ & $\begin{array}{l}\text { Delay to road users } \\
\text { Disruption to businesses } \\
\text { Disruption to local community } \\
\text { Health and safety } \\
\text { Impact on local authorities assets } \\
\text { Visual intrusion }\end{array}$ \\
\hline $\begin{array}{l}\text { Operation and maintenance } \\
\text { (long-term) social impact }\end{array}$ & $\begin{array}{l}\text { Delay to road users } \\
\text { Disruption to businesses } \\
\text { Disruption to local community } \\
\text { Health and safety } \\
\text { Impact on local authorities assets } \\
\text { Visual intrusion }\end{array}$ \\
\hline $\begin{array}{l}\text { Construction (short-term) } \\
\text { environmental impact }\end{array}$ & $\begin{array}{l}\text { Construction emissions } \\
\text { Energy } \\
\text { Water, wastewater and drainage } \\
\text { Materials and waste } \\
\text { Streetscape and biodiversity } \\
\text { Soil and land }\end{array}$ \\
\hline $\begin{array}{l}\text { Operation and maintenance } \\
\text { (long-term) environmental } \\
\text { impact }\end{array}$ & $\begin{array}{l}\text { Maintenance emissions } \\
\text { Energy } \\
\text { Water, wastewater and drainage } \\
\text { Materials and waste } \\
\text { Streetscape and biodiversity } \\
\text { Soil and land }\end{array}$ \\
\hline
\end{tabular}

in ATU's decision support system, thereby bringing a new level of intelligence to the planning and execution of streetworks.

\section{Case study - trenchless against trenching}

To demonstrate the application of the pre-appraisal sustainability tool, a case study that was originally developed by Michielsen $(2005,2006)$ and was further investigated and quantified by Matthews et al. (2015) has been re-analysed in this research. The case involves replacement and upgrading of a combined sewer system in Kessel-Dorp in the town of Kessel, Nijlen in Belgium. The aim was to add a new wastewater collector and reinstallation of the service lines as a separated sewer system to replace the existing combined sewer system. Two scenarios were developed for this project using different underground construction techniques: open-cut trenching and pipe-jacking as a trenchless alternative. In the open-cut trenching scenario, a new wastewater collector, the storm water collector and all service line connections had to be constructed. However, in the pipe-jacking option, it was feasible to convert the existing collector to a storm drain and to place the new collector below the existing one. During the construction phase, parts of the road system where the construction site was located had to be closed and the traffic diverted. This increased the travel distance by $11.7 \mathrm{~km}$ for both scenarios. The road had to be partially, and occasionally fully, closed for 8 months in the open-cut trenching scenario, whereas the road closure was as short as 1 month for the pipe-jacking alternative. Traffic delay costs were calculated (Table 4) by Matthews et al. (2015) using the lost time value as $£ 53 / \mathrm{h}$ for lorries, $£ 26 / \mathrm{h}$ for delivery vehicles and $£ 16 / \mathrm{h}$ for passenger cars (prices converted from US dollars to UK pounds using US $\$ 1=£ 0.78$ in June 2017; Oanda, 2017). Moreover, it was reported that there were 60 businesses with a total annual turnover of $£ 2.96$ million (using the same conversion factor) located in close proximity to the construction site. Matthews et al. (2015) assumed the loss as a result of disruption to businesses to be a $70 \%$ loss in sales revenues when there was a blocked access to the business, and 33\% loss in the case of difficult access to the business. A summary of project information as well as the quantified impacts and costs are shown in Table 4.

To apply the ATU sustainability indicator system and assessment method to this case study, the final sets of the indicator and the main criteria (Table 3) were employed within the tool. A preliminary review of the criteria was conducted to ensure their relevance to the case study, and published project information and data (Table 4) translated to relevant costs and impacts within the assessment tool. Two assessments were carried out for each alternative method - one for construction (short term, Figures 8(a) and 8(b)) and the other for operation and maintenance (long-term, Figures 9(a) and 9(b)) - and the assessment outputs were compared. The assessments were carried out by employing the tool modified with the new suite of criteria for utility streetworks. The results of the assessment for both short and long term for the two alternatives were then presented as standard colour-coded SPeAR ${ }^{\circledR}$ diagrams (Figures 8 and 9).

As demonstrated in Figure 8, the assessment outputs for the two options indicate the areas of sustainability strength and weakness for the two alternative construction methods. Pipejacking, as a trenchless technology, performs much better in terms of the social and environmental criteria for the construction (short-term) stage of this project. Notably, pipe-jacking has far fewer negative impacts for delay to road users and disruption to businesses, as is evident from the cost data (Table 4), yet this assessment reaches far beyond these two aspects (i.e. main criteria) of adverse consequences, for which the indirect costs are readily calculated. In terms of social impacts, it causes 
Table 4. Project information and impact/cost quantification data for Kessel-Dorp sewer system upgrade project (Adapted from Michielsen (2005, 2006) and Matthews et al. (2015))

\begin{tabular}{llll} 
Project information and cost data $^{a}$ & Unit & Open-cut trenching scenario & Trenchless (pipe-jacking) scenario \\
\hline Project duration & $\mathrm{d}$ & 300 & 200 \\
Construction duration & $\mathrm{d}$ & 216 & 144 \\
Pipe length & $\mathrm{m}$ & 2500 & 2500 \\
Pipe diameter & $\mathrm{mm}$ & 1200 and 1600 & 600,1200 and 1600 \\
Trench depth & $\mathrm{m}$ & $2 \cdot 9$ to $4 \cdot 4$ & Deeper than open-cut trench \\
Road closure & $\mathrm{months}$ & 8 & 1 \\
Travel distance increase & $\mathrm{km}$ & $11 \cdot 7$ & $11 \cdot 7$ \\
Direct contract costs & $\mathrm{f}$ & 4321620 & 586897 \\
Direct cost per metre of placed pipe & $\mathrm{f} / \mathrm{m}$ & 1728 & 2235 \\
Increased fuel cost & $\mathrm{f}$ & 434841 & 53757 \\
Traffic diversion cost & $\mathrm{f}$ & 1428168 & 382380 \\
Delay (time) costs to idling vehicles on diverted routes & $\mathrm{f}$ & 431464 & 53340 \\
Lost business revenue & $\mathrm{f}$ & 442081 & 54656 \\
Total indirect costs (criteria in italics) & $\mathrm{f}$ & 2736554 & 544133 \\
Indirect costs per metre of placed pipe & $\mathrm{f} / \mathrm{m}$ & 1095 & 218 \\
Indirect costs per construction duration & $\mathrm{f} / \mathrm{d}$ & 12669 & 3779 \\
Total indirect costs as \% of direct contract costs & $\%$ & 63 & 10 \\
True total costs & $\mathrm{f}$ & 7058174 & 6131030 \\
True total costs per metre of placed pipe & $\mathrm{f} / \mathrm{m}$ & 2823 & 2452
\end{tabular}

${ }^{\text {a }}$ All cost values were converted from USD to GBP using conversion factor 1 USD $=0.78$ GBP in June 2017 (OANDA, 2017)
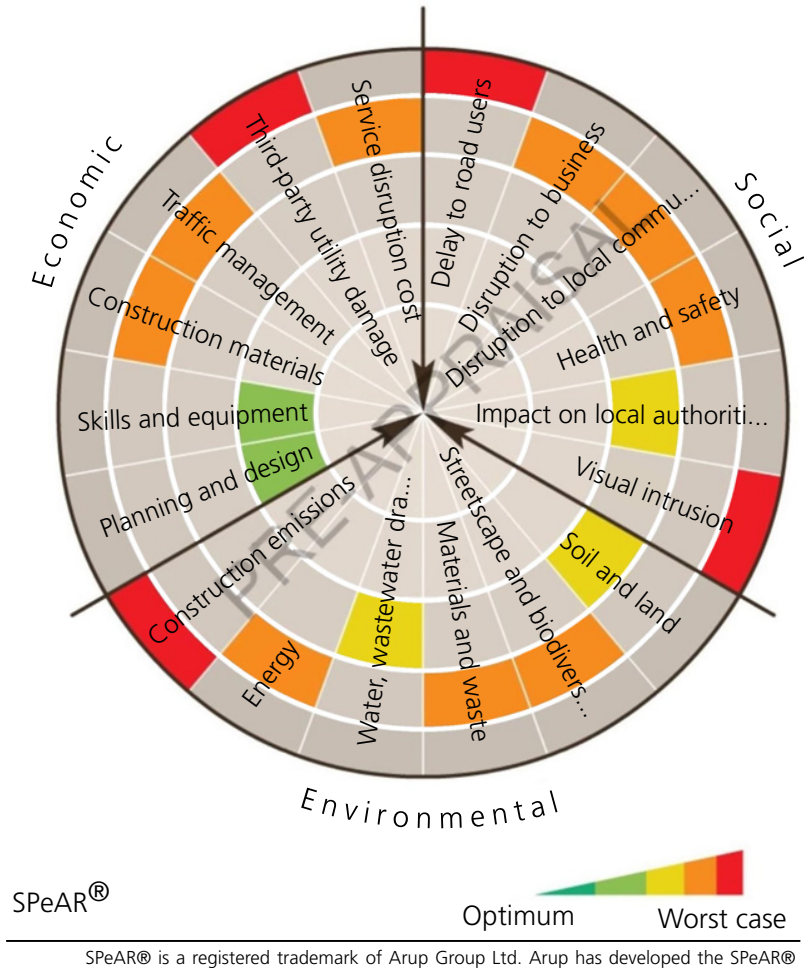
appraisal framework, but takes no responsibility for the content of an individual appraisal

(a)
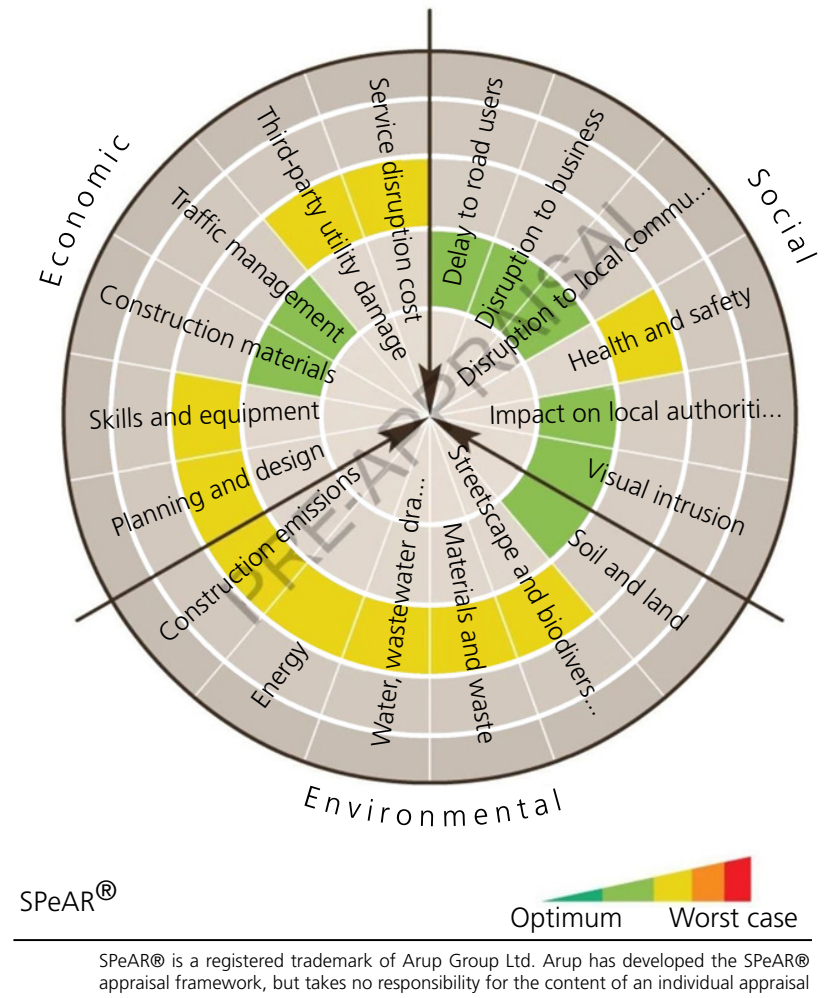

(b)

Figure 8. Sustainability pre-appraisal outputs for the construction stage of the case study for two alternatives: (a) open-cut trenching and (b) pipe-jacking (produced under Oasys Software Unipac Engineering Suite for Research Licence). A full-colour version of this figure can be found on the ICE Virtual Library (www.icevirtuallibrary.com) 


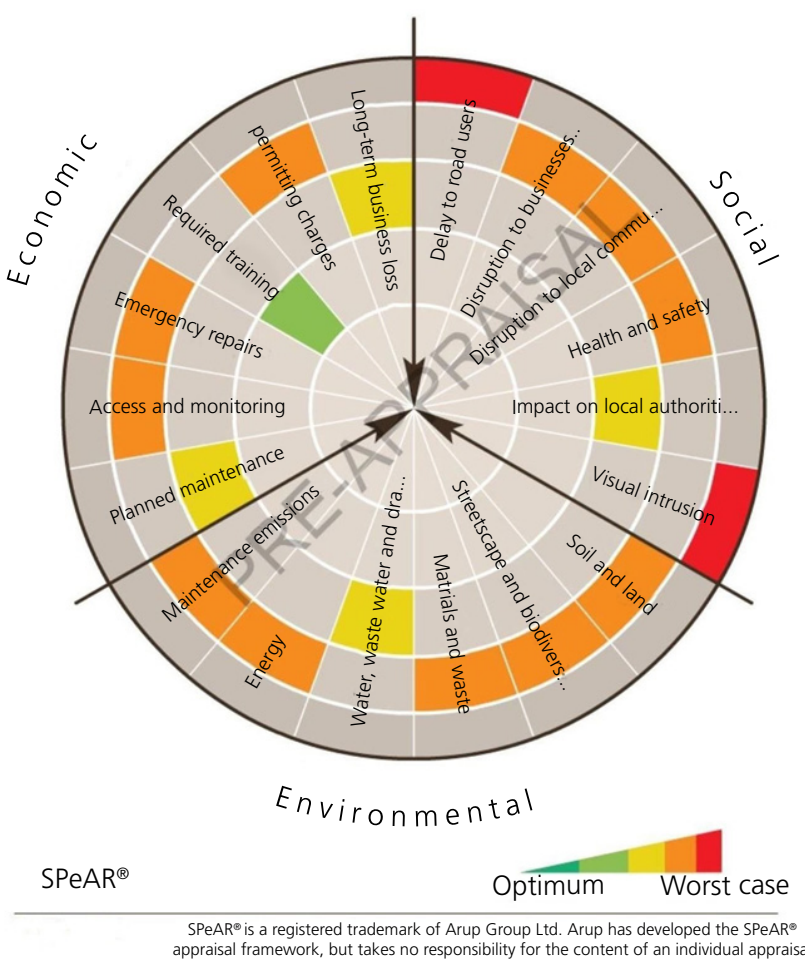

(a)

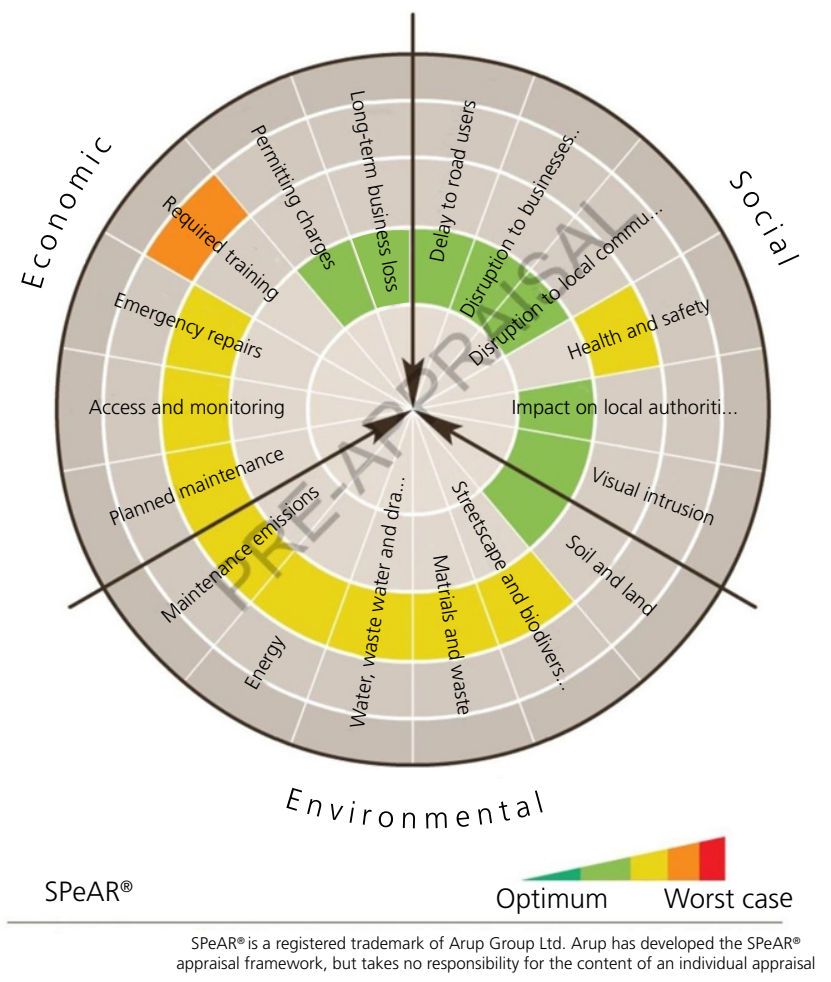

(b)

Figure 9. Sustainability pre-appraisal outputs for the operation and maintenance stage of the case study for two alternatives: (a) open-cut trenching and (b) pipe-jacking (produced under Oasys Software Unipac Engineering Suite for Research Licence). A full-colour version of this figure can be found on the ICE Virtual Library (www.icevirtuallibrary.com)

far less disruption to local communities and visual intrusion (thereby reducing negative local perceptions of 'the brand' of the organisation carrying out the work) and damage to local authority assets (which are funded by local and/or national taxation), and importantly reduces health and safety risks. The environmental impacts due to increased energy consumption, emissions, material consumption and wastage, and temporary harm to the streetscape, biodiversity, soil and land, are likewise markedly reduced. These social and environmental impacts are harder to quantify in monetary cost terms, but assume considerable importance for different stakeholders; put another way, reducing these adverse impacts effectively adds value to the project, and this might translate also into political value in terms of the political rewards for those who govern streetworks in looking after the interests of those affected.

It should be noted that pipe-jacking does not always perform better: sustainability has an economic pillar. Open-cut trenching is less expensive in direct contract costs and in cost per metre of placed pipe, and hence scored better in the planning and design criterion. Similarly, open-cut trenching scored better for skills and equipment as it is a tried and tested technique, which has been in use for many years, with appropriate knowledge and practice base, compared to the lessfrequently employed trenchless technologies (although trenchless industry professionals might argue differently on this point). One uncertainty that arises concerns the potential damage to buried assets from trenchless operations: open-cut trenching uncovers the buried infrastructure as it proceeds and, although there will almost certainly be damage caused to the existing asset base (cuts in roads reduce road life, lateral stressrelief movement softening and weakening the ground and compromising its long-term support for buried and surface assets, construction operations in the vicinity of exposed pipes and cables, etc.), it is potentially less unknown than when operating trenchlessly. It is for this reason that more effort, and cost, is involved in planning and design to understand (possibly using geophysical surveys) the precise location of the existing buried infrastructure (Rogers et al., 2008), and ideally why attempts should be made also to assess the condition of the buried infrastructure (Rogers, 2015; Rogers et al., 2012a). However, if this is done then the risk of the third-party damage is greatly reduced compared to open-cut trenching. Moreover, the costs for the four other economic main criteria are markedly 
reduced, and so an overall engineering judgement is needed for this sustainability pillar.

The assessment for the operation and maintenance stage (Figure 9), as might be expected, provides a different perspective on sustainability performance. Although for social criteria, such as delay to road users, disruption to businesses and health and safety, the assessments show relatively similar outputs for both construction and operation and maintenance stages of the two engineering alternatives, it can be seen that, for example, for the open-cut method, the emissions criterion performs slightly better in the operation and maintenance stage than in construction stage. This is due to the less-intensive nature of the work normally being carried out for opencut trenching in maintenance activities compared to the initial construction. However, the soil and land criterion for the trenching method during the operation and maintenance stage does not perform as well as it does at construction stage. This point is justified by considering the potentially numerous excavation and reinstatement operations throughout the operation and maintenance lifecycle of the project. The primary influence at this stage concerns the longer-term damage caused by open-cut trenching, which is likely to require repairs to the road surface in the vicinity of the trenches and/or earlier road reconstruction as the slab action of the road is compromised, and potentially earlier repair or maintenance of buried utilities due to the long-term damage due to its compromised ground support. This results in poorer performance across all three pillars of sustainability generally.

\section{Discussion}

The above discussion and evaluation are necessarily directly relevant to the case study. Country and/or area-specific factors always have an influence on the results of an assessment, and a full appreciation of the local context of the works is therefore crucial. For some of the main criteria, such as impacts on the streetscape, biodiversity, local authorities' assets and visual intrusion, there was insufficient information from the published case study to support the assessment, and hence assumptions were necessary. To bring a greater degree of rigour and validation to these assumptions, evaluation and scoring of these main criteria for the case study were carried out in consultation with three experts from the fields of utilities, roads and construction, and sustainability, each drawing on their experience from similar past projects to provide calibration and validation to the assessment. Similarly, when applying this methodology to any practical situation there might be a need for assumptions to be made; this does not render the methodology valueless, but it is important that assumptions are reported as such and their application is wholly transparent so that evidence-based engineering judgements can be made.
The application of the headline indicators and the associated criteria for the short- (construction) and long-term (operation and maintenance) stages of a utility infrastructure streetworks project in the pre-appraisal tool helps to provide a better understanding of the consequences of the alternative approaches that might be taken to solve a particular problem. The aim is to provide to the engineer detailed, transparent, value-based and comprehensive assessments of alternatives in terms of benefits, costs, opportunities and risks associated with each of the engineering methods. Crucially, it is an enabler of better decision making, but it removes no responsibility from the engineer - it does not itself make decisions.

The alternative engineering solutions to a problem of utility placement, repair, refurbishment, replacement or up-sizing are clearly not limited to a comparison between open-cut trenching and a single trenchless alternative: there are many trenchless technologies, and more long-term (future-proofed) sustainable options such as MUTs (Hunt et al., 2014), and all such alternatives should be considered. Only in this way can all of the benefits, which accrue differentially to different stakeholders, and all costs, which likewise are incurred differentially by different stakeholders, be apportioned to reach an equitable outcome, whether this is to deliver sustainability, resilience or liveability, and whether the focus is primarily on the economic pillar of sustainability or more evenly distributed across all three pillars.

\section{Conclusions}

Due to the critical importance of underground utility infrastructure in maintaining the effective functioning of systems and services in urban areas, both the short- and long-term consequences of engineering interventions in this system of systems, which usually takes the form of streetworks, must be assessed. A new suite of headline indicators and associated performance criteria, coupled with an assessment method based on the modification of an existing sustainability evaluation tool, is proposed herein. This pre-appraisal tool, which can be used as part of a wider project sustainability evaluation framework, addresses the consequences of the construction (short-term) and operation and maintenance (long-term) stages of a project.

It has been applied to a case study of a sewer replacement project in Belgium to assess outputs for two alternative engineering approaches: open-cut trenching and trenchless technology using pipe-jacking. The short- and long-term impacts demonstrated that a far better performance was achieved for pipe-jacking compared to the open-cut method when judged across all three pillars of sustainability. While this conclusion had been reached by others, previous analyses have been limited to a narrow range of social costs to which monetary values could be apportioned. The far more comprehensive, 
Urban Design and Planning

Volume 170 Issue DP6
Embedding sustainability criteria into pre-appraisal of underground utility for future cities

Hojjati, Jefferson, Metje and Rogers and detailed, sustainability assessment, and the context-dependent narratives that accompany them, serve to bring a new level of intelligence to the planning, operation and maintenance activities for streetworks. Specifically, this will in turn inform those responsible for decision-making in streetworks projects of the likely outcomes of their decisions in terms of direct and indirect economic, social and environmental impacts. Importantly it enables decision makers to consider a wide variety of alternative engineering solutions to a particular problem, including the adoption of longer-term options such as multi-utility tunnels or other multiple value-generating engineering alternatives, the associated benefits of which will manifestly contribute to more sustainable, resilient and liveable future cities.

\section{Acknowledgements}

The authors gratefully acknowledge the financial support of UK's Engineering and Physical Sciences Research Council (EPSRC) for research carried out in the Assessing The Underworld (grant reference EP/K021699), Resilience of Critical Local Transport and Utility Infrastructures (EP/I016133), Liveable Cities (EP/J017698) and iBUILD: Infrastructure BUsiness models, valuation and Innovation for Local Delivery (EP/K012398) projects.

\section{REFERENCES}

Ariaratnam ST, Piratla K, Cohen A and Olson M (2013) Quantification of sustainability index for underground utility infrastructure projects. Journal of Construction Engineering and Management 139(12): 31-38.

Arup (2017) $S P e A R^{\circledR}$ (Sustainable Project Appraisal Routine). Arup, London, UK. See http://www.arup.com/projects/spear.aspx (accessed 20/05/2017).

Braithwaite P (2007) Improving company performance through sustainability assessment. Proceedings of the ICE, Engineering Sustainability 160(2): 95-103, http://dx.doi.org/10.1680/ensu.2007. 160.2.95.

Braithwaite PA and Cowell JR (2007) Acoustics and sustainability. In Institute of Acoustics Spring Conference 2007: Sound of Sustainability: Going for Gold! (Sondo V, Warren C and Rogers P (eds)). Institute of Acoustics, St Albans, UK, pp. 10-18.

BSI (2014) PAS 128: 2014 Specification for underground utility detection, verification and location. BSI, London, UK.

Dawson RJ, Walsh CL, Purnell P and Rogers CDF (2014) Briefing: Infrastructure business models, valuation and innovation for local delivery. Infrastructure Asset Management 1(3): 66-67, https://doi.org/10.1680/iasma.14.00027.

Gallienne B (2016) Delivering growth - the legislative and practical realities. National Joint Utilities Group (NJUG). Presentation at EUA Utility Street Works Conference: New Approaches for Critical Infrastructure, London, UK. Energy and Utilities Alliance (EUA), London, UK.

Hayes R, Chapman DN, Metje N and Rogers CDF (2012) Sustainability assessment of UK streetworks. Proceedings of the Institution of Civil Engineers, Municipal Engineer 165(4): 193-204, http://dx.doi. org/10.1680/muen.12.00004.
Hojjati A, Jefferson I, Metje N and Rogers CDF (2016) Sustainable asset management for utility streetworks. In Transforming the Future of Infrastructure through Smarter Information: Proceedings of the International Conference on Smart Infrastructure and Construction (ICSIC 2016) (Mair RJ, Soga K, Jin Y, Parlikad AL and Schooling JM (eds)). ICE Publishing, London, UK, pp. 669-674.

Hojjati A, Jefferson I, Metje N and Rogers CDF (2017) Sustainability assessment for urban underground utility infrastructure projects. Proceedings of the Institution of Civil Engineers-Engineering Sustainability 1-13, http://dx.doi.org/10.1680/jensu.16.00050. Holt DGA, Jefferson I, Braithwaite PA and Chapman DN (2010) Embedding sustainability into geotechnics. Part A: methodology. Proceedings of the Institution of Civil Engineers, Engineering Sustainability 163(3): 127-135, http://dx.doi.org/10.1680/ensu.2010. 163.3.127.

Hunt DVL and Rogers CDF (2015) Aspirational City Futures: 3 Models for City Living. Foresight, Government Office for Science, London, UK. See http://www.gov.uk/government/publications/ future-of-cities-aspirational-scenarios (accessed 09/10/2017).

Hunt DV, Lombardi DR, Rogers CDF and Jefferson I (2008) Application of sustainability indicators in decision-making processes for urban regeneration projects. Proceedings of the Institution of Civil Engineers-Engineering Sustainability 161(1): 77-91, http://dx.doi.org/10.1680/ensu.2008.161.1.77.

Hunt DVL, Nash D and Rogers CDF (2014) Sustainable utility placement via multi-utility tunnels. Tunnelling and Underground Space Technology 39: 15-26, https://doi.org/10.1016/j.tust.2012.02.001. Hunt DVL, Makana LO, Jefferson I and Rogers CDF (2016) Liveable cities and urban underground space. Tunnelling and Underground Space Technology 55: 8-20, https://doi.org/10.1016/ j.tust.2015.11.015.

Jefferson I, Hunt DVL, Birchall CA and Rogers CDF (2007) Sustainability indicators for environmental geotechnics. Proceedings of the ICE, Engineering Sustainability 160(2): 57-78, http://dx.doi.org/ 10.1680/ensu.2007.160.2.57.

Jung YJ (2012) Evaluation of subsurface utility engineering for highway projects: benefit-cost analysis. Tunnelling and Underground Space Technology 27: 111-122, http://dx.doi.org/ 10.1016/j.tust.2011.08.002.

Jung YJ and Sinha SK (2007) Evaluation of trenchless technology methods for municipal infrastructure system. Journal of Infrastructure Systems 13(2): 144-156.

Koo DH, Ariaratnam ST and Kavazanjian E (2009) Development of a sustainability assessment model for underground infrastructure projects. Canadian Journal of Civil Engineering 36(5): 765-776.

Laefer DF (2011) Quantitative support for a qualitative foundation reuse assessment tool. In Geo-Frontiers 2011: Advances in Geotechnical Engineering (Han J and Alzamora DA (eds)). ASCE, Reston, VA, USA, pp. 113-121.

Leach JM, Braithwaite PA, Lee SE et al. (2017) Measuring urban sustainability and liveability performance: the city analysis methodology. International Journal of Complexity in Applied Science and Technology 1(1): 86-106.

Lombardi DR, Porter EJ, Barber ARG and Rogers CDF (2011) Conceptualising sustainability in UK urban regeneration: a discursive formation. Urban Studies 48(2): 273-296.

Lombardi DR, Leach JM, Rogers CDF et al. (2012) Designing Resilient Cities - A Guide To Good Practice. IHS BRE Press, Bracknell, UK.

Makana L, Metje N, Jefferson I and Rogers CDF (2016) What Do Utility Strikes Really Cost? A Report by the 
University of Birmingham - School of Civil Engineering, Birmingham, UK.

Masood T, Mcfarlane D, Parlikad AK et al. (2016) Towards the future-proofing of UK infrastructure. Infrastructure Asset Management 3(1): 28-41, https://doi.org/10.1680/jinam.15.00006.

Matthews JC, Allouche EN and Sterling RL (2015) Social cost impact assessment of pipeline infrastructure projects. Environmental Impact Assessment Review 50: 196-202, https://doi.org/10.1016/ j.eiar.2014.10.001.

McGregor A and Roberts C (2003) Using the Spear ${ }^{\mathrm{TM}}$ assessment tool in sustainable master planning. In Proceedings of US Green Building Conference, Pittsburgh, PA, USA (Kibert CJ (ed.)). US Green Building Council, Pittsburgh, PA, USA, pp. 1-12.

McMahon W, Burtwell M and Evans M (2006) Minimising Street Works Disruption: The Real Costs of Street Works to the Utility Industry and Society. UK Water Industry Research, London, UK.

Metje N, Atkins P, Brennan M et al. (2007) Mapping the underworldstate-of-the-art review. Tunnelling and Underground Space Technology 22(5): 568-586.

Metje N, Ahmad B and Crossland SM (2015) Causes, impacts and costs of strikes on buried utility assets. Proceedings of the ICE - Municipal Engineer 168(3): 165-174, http://dx.doi.org/10 1680/jmuen.14.00035.

Michielsen K (2005) Indirect costs of sewer installations: comparison of the total costs of open trench and jacking alternatives based on a specific project. No-Dig Rotterdam. International Society for Trenchless Technology (ISTT), London, UK.

Michielsen K (2006) Trench vs jacking cost comparison. Tunnels \& Tunnelling International, 14 June: pp. 23-26.

Najafi M and Kim KO (2004) Life-cycle-cost comparison of trenchless and conventional open-cut pipeline construction projects. In Pipeline Engineering and Construction: What's on the Horizon? (Galleher JJ Jr and Stift MT (eds)). ASCE, Reston, VA, USA, pp. 1-6.

OANDA (2017) Foreign Exchange Company. OANDA, New York, NY, USA. See https://www.oanda.com/currency/converter/ (accessed $15 / 06 / 2017)$.

Oasys (2012) SPeAR ${ }^{\circledR}$ Handbook 2012 External Version. Oasys, London, UK. See https://www.oasys-software.com/media/manuals/ latest_manuals/spear_manual.pdf (accessed 10/10/2016).
Oasys (2017) SPeAR ${ }^{\circledR}$ Pre-Appraisal. Oasys, London, UK. See http://www.oasys-software.com/spear-pre-appraisal.html (accessed 01/06/2017).

Pearce OJD, Murry NJA and Broyd TW (2012) Halstar: systems engineering for sustainable development. Proceedings of the Institution of Civil Engineers, Engineering Sustainability 165(2): 129-140, http://dx.doi.org/10.1680/ensu.9.00064.

Rogers CDF (2015) Assessing the underworld - remote sensing to support smart and liveable cities. Proceedings of the 8th International Workshop on Advanced Ground Penetrating Radar (IWAGPR 2015), Florence, Italy. IEEE, Piscataway, NJ, USA, pp. $1-4$.

Rogers CDF (2017) Application of foresight in engineering future sustainable, resilient and liveable cities. Proceedings of the Institution of Civil Engineers, Civil Engineering (in press).

Rogers CDF and Hunt DVL (2006) Sustainable utility infrastructure via multi-utility tunnels. Proceedings of the Canadian Society of Civil Engineering 2006 conference, Towards a Sustainable Future, Calgary, Canada. Canadian Society of Civil Engineering (CSCE), Montreal, QC, Canada, pp. CT-001-1-CT-001-10.

Rogers CDF, Royal ACD, Thomas AM et al. (2008) Locating all buried assets without the need for excavation: the mapping the underworld project. Trenchless International, 1 October: pp. 40-43.

Rogers CDF, Hao T, Costello SB et al. (2012a) Condition assessment of the surface and buried infrastructure - a proposal for integration. Tunnelling and Underground Space Technology 28: 202-211, https://doi.org/10.1016/j.tust.2011.10.012.

Rogers CDF, Bouch CJ, Williams S et al. (2012b) Resistance and resilience - paradigms for critical local infrastructure. Proceedings of the Institution of Civil Engineers, Municipal Engineer 165(2): 73-84, http://dx.doi.org/10.1680/muen.11.00030.

Sahely HR, Kennedy CA and Adams BJ (2005) Developing sustainability criteria for urban infrastructure systems. Canadian Journal of Civil Engineering 32(1): 72-85.

Zargarian R, Hunt DVL, Braithwaite P, Bobylev N and Rogers CDF (2016) A new sustainability framework for urban underground space. In Proceedings of the Institution of Civil Engineers-Engineering Sustainability. Thomas Telford Ltd, https://doi.org/10.1680/jensu. 15.00013 .

\section{How can you contribute?}

To discuss this paper, please email up to 500 words to the editor at journals@ice.org.uk. Your contribution will be forwarded to the author(s) for a reply and, if considered appropriate by the editorial board, it will be published as discussion in a future issue of the journal.

Proceedings journals rely entirely on contributions from the civil engineering profession (and allied disciplines).

Information about how to submit your paper online is available at www.icevirtuallibrary.com/page/authors, where you will also find detailed author guidelines. 